\title{
PERANAN SOSIALISASI NILAI KEBERSAMAAN DALAM UPAYA MENANGGULANGI KONFLIK BERAGAMA DALAM KEHIDUPAN BERMASYARAKAT DI KOTA PALANGKA RAYA
}

\author{
Desi Erawati \\ Institut Agama Islam Negeri (IAIN) Palangka Raya \\ Jl. G. Obos, Menteng, Jekan Raya, Palangka Raya, Kalimantan Tengah 74874, Indonesia \\ E-mail: desi hana09@yahoo.com
}

\begin{abstract}
Forum Kerukunan Antar Umat Beragama (FKUB) is a mediating institution on interfaith harmony, especially in the city of Palangkaraya. The question is how the value model of socialization of the value of togetherness conducted by FKUB Palangka Raya city so that it can bridge the life of tolerance between religious communities in the city of Palangka Raya. The methodology of this study is to use a research and development approach with a modified analysis of Miles and Huberman. The results of this study indicate that the working pattern of FKUB Palangka Raya works in accordance with the planned work program, proved to be able to handle several cases related to the establishment of houses of worship and its scope, prioritize the objectivity to produce mutually agreed decisions based on consensus reached agreement. The development of socialization of the value of togetherness is derived from several values such as the value of ideology (universal truth), religious values, cultural values. By way of coaching, intensive direction, then this togetherness attitude can be well established, especially supported by the value of local wisdom is the philosophy of "Huma Betang"
\end{abstract}

Keywords: Socialization, Togetherness Value, FKUB

\begin{abstract}
Abstrak
Forum Kerukunan Antar Umat Beragama (FKUB) merupakan lembaga mediator tentang kerukunan antar umat beragama khususnya di kota Palangka Raya. Menjadi pertanyaan adalah bagaimana model nilai sosialisasi nilai kebersamaan yang dilakukan oleh FKUB kota Palangka Raya sehingga dapat menjembatani kehidupan toleransi antar umat beragama di kota Palangka Raya. Adapun metodologi kajian ini adalah menggunakan pendekatan research and development dengan modifikasi analisa Miles dan Huberman. Hasil penelitian ini menunjukkan bahwa pola kerja FKUB kota Palangka Raya bekerja sesuai dengan program kerja yang direncanakan, terbukti dapat menangani beberapa kasus berkaitan dengan pendirian rumah ibadah dan ruang lingkupnya, mengedepankan sisi obyektivitas untuk menghasilkan keputusan yang disepakati bersama berdasarkan musyarawarah mencapai mufakat. Pengembangan sosialisasi nilai kebersamaan itu didapatkan dari beberapa nilai seperti nilai ideologi (kebenaran universal), nilai agama, nilai Budaya. Dengan cara pembinaan, pengarahan yang intensif maka sikap kebersamaan ini bisa terjalin dengan baik, terutama didukung oleh nilai kearifan lokal yaitu filosofi "Huma Betang"
\end{abstract}

Kata Kunci,: Sosialisasi, Nilai Kebersamaan, FKUB. 


\section{PENDAHULUAN}

Konflik sosial sebetulnya merupakan gejala yang universal, artinya suatu peristiwa yang dapat dijumpai dan terjadi di dalam setiap masyarakat dimanapun dan kapanpun. ${ }^{1}$ Konflik sosial dapat terjadi dalam lingkup kecil, menengah dan besar seperti pada organisasi, keluarga, komunitas, masyarakat, negara dan dunia, dapat melibatkan individu dengan individu, kelompok dengan kelompok, komunitas dengan komunitas, atau bangsa dengan bangsa.

Kasus bernuansa keberagamaan yang menjadi fokus penelitian ini adalah yang berkaitan dengan nuansa keberagamaan seperti di beberapa kasus lain ${ }^{2}$. Contohnya tentang konflik pendirian rumah ibadah, dapat terlihat di beberapa daerah di Bekasi dan Depok, modusnya adalah pendirian rumah ibadah yang ada tidak sesuai dengan jumlah penduduk sekitar atau tidak adanya surat rekomendasi dari Forum Kerukunan Umat Beragama dimana pemerintah memfasilitasi buat masyarakat hal- hal yang berkenaan dengan pendirian rumah ibadah atau konflik antar umat beragama, FKUB sebagai salah satu media untuk menjembatani semua aspirasi masyarakat khususnya tentang peraturan pendirian rumah ibadah .

Dari beberapa gambaran berbagai macam konflik yang bernuansa agama, peneliti mencoba untuk menelaah lebih jauh berawal dari penyelesaian konflik yang ada di kota Palangka Raya dengan jalan damai, beberapa peristiwa yang terjadi khususnya di kota Palangka Raya, beberapa contoh yang bisa menjadi potensi konflik antar agama yang bisa diselesaikan oleh FKUB kota Palangka Raya, diantaranya sebagai berikut :

1. Penyelesaian masalah tentang alat pengeras mesjid di daerah Panarung

2. Pendirian rumah ibadah di jalan Kutilang

3. Beralih fungsinya rumah pribadi atau pertokoan menjadi tempat ibadah secara kontinu

4. Misunderstanding terhadap pemahaman antar umat beragama yang diselesaikan di mushola tepatnya di jalan Km. 3.5

5. Penyelesaian masalah tentang alat pengeras mesjid yang terjadi di dekat kantor Polres kota Palangka Raya Km. 3.5

6. Pendirian rumah ibadah di Pahandut Seberang kota Palangka Raya ${ }^{3}$

${ }^{1}$ Doyle Paul Johson, Teori Sosiologi Klasik Dan Modern, II (Jakarta: PT. Gramedia Pustaka Utama, 1986), 134.

2 “-," Republika, September 15, 2010.

${ }^{3}$ FKUB Kota Palangka Raya, Laporan Keberadaan Dan Aktivitas FKUB Kota Palangka Raya (Kalimantan Tengah Palngka Raya: FKUB, 2009). 
Penelitian difokuskan pada sebuah pertanyaan besar yaitu model sosialisasi nilai kebersamaan yang bagaimana dapat menjembatani FKUB dengan masyarakat guna mengurangi konflik antar umat keberagamaan yang ada di kota Palangka Raya. Untuk menjawab pertanyaan itu bagaimana kondisi obyektif sosialisasi nilai kebersamaan yang dilakukan FKUB, dan bagaimana pengembangan model konseptual sosialisasi nilai kebersamaan. Terakhir bagaimana efektivitas dari pengembangan model sosialisasi nilai kebersamaan tersebut.

Sosialisasi merupakan suatu hal yang mendasar bagi perkembangan kita sebagai manusia. Berinteraksi dengan orang lain, kita belajar bagaimana berpikir, mempertimbangkan dengan nalar, dan berperasaan. Hasil akhirnya ialah pembentukan perilaku kita termasuk pikiran dan emosi kita sesuai dengan standar budaya. ${ }^{4}$

Menurut Narwoko, ada dua aspek yang terjadi dalam melaksanakan sosialisasi. Pertama, orang-orang yang punya wibawa dan kekuasaan atas individu-individu yang disosialisasi disebut sosialisasi otoriter, misalnya, ayah, ibu, guru, atasan, dan pemimpin. Kedua, orang-orang yang mempunyai kedudukan sederajat dengan individu-individu yang tengah disosialisasi disebut sosialisasi ekualitas, misalnya saudara sebaya, kawan sepermainan, atau kawan sekelas 5 . Sosialisasi dari kelompok yang bersifat otoriter terjadi dalam rangka penyebaran nilai-nilai sosial agar patuh dan menghormati nilai-nilai sosial yang ada dalam kehidupan masyarakat, sedangkan sosialisasi ekualitas adalah melalui kerjasama yang koordinatif dan kooperatif dalam penyebaran nilai-nilai sosial tersebut. Berger mendefinisikan sosialisasi sebagai "a procces by which a child learns to be a participant member of society"...proses melalui mana seorang anak belajar menjadi seorang anggota yang berpartisipasi dalam masyarakat (Berger, 1978). Menurut Berger dan sejumlah tokoh sosiologi lainnya yang diajarkan melalui sosialisasi ialah peran-peran. ${ }^{6}$

Sosialisasi adalah suau proses pembelajaran dan pembinaan tujuannya adalah agar manusia dalam kehidupannya bisa beradaptasi dan mengikuti norma-norma yang ada dimasyarakat, pendapat demikian sesuai dengan teorinya Emile Durkheim dimana manusia dalam kehidupannya menginginkan adanya keseimbangan dalam bermasyarakat inilah yang disebut dengan fakta sosial sedangkan konsep utamanya adalah integritas sosial, tertib sosial dan solidaritas (mekanis dan organik). Dalam hal ini lebih

\footnotetext{
${ }^{4}$ James M Henslin, Sosiologi Dengan Pendekatan Membumi, 6th ed., 1 (Jakarta: Erlangga, 2006), 74.

${ }^{5}$ J.D. Narwoko and Suyanto B, Sosiologi, Teks Pengantar Dan Terapan, 2nd ed. (Jakarta: Prenada Media Group, 2006), 77.

${ }^{6}$ Kamanto Sunarto, Pengantar Sosiologi, Edisi Revisi (Jakarta: UI Press, 2004).
} 


\section{4| Desi Erawati}

memfokuskan pada solidaritas yang menunjuk pada satu keadaan hubungan antara individu/atau kelompok yang didasarkan pada perasaan moral dan kepercayaan yang dianut bersama diperkuat oleh pengalaman emosional bersama. Parson mengatakan bahwa semua teori-teori besar yang ia teliti merupakan suatu gerakan yang mengarah kepada apa yang disebutnya "teori tindakan voluntaristik", yakni manusia dipahami sewaktu dia membuat pilihan atau keputusan antara tujuan yang berbeda dan alat-alat untuk mencapainya. Unit tindakan terbentuk oleh pelaku, alat-alat, tujuan-tujuan dan suatu lingkungan yang terdiri dari obyek-obyek fisik dan sosial, normanorma dan nilai-nilai. Ini merupakan deskripsi abstrak dari semua tindakan yang merupakan titik-tolak dari skema Parson. ${ }^{7}$

Dalam analisa Parsons tentang tindakan voluntaristik adalah bahwa (1) tindakan itu diarahkan pada tujuannya (atau memiliki satu tujuan); 2) tindakan terjadi dalam suatu situasi, dimana beberapa elemennya sudah pasti; 3) secara normatif tindakan itu diatur sehubungan dengan penentuan alat dan tujuan. Singkatnya, tindakan itu dilihat sebagai satuan kenyataan sosial yang paling kecil dan paling fundamental. Komponen-komponen dasar dari suatu tindakan adalah tujuan, alat, kondisi dan norma. ${ }^{8}$

Dari beberapa teori yang sudah dijelaskan di atas tersebut, disini juga mengkaji tentang teori yang lain seperti multikultural adalah faham bahwa dunia dan masyarakat terdapat adanya beragam komuniti dengan budaya berbeda tetapi sederajat. Dua macam multikulturalisme: pertama, multikultural deskriptif yaitu pemahaman tentang kenyataan adanya pluralitas masyarakat dan budaya. Kedua, multikultural normatif yaitu niat untuk bersatu dalam keanekaragaman. Latar belakang filosofis multikulturalisme adalah masyarakat penuh dengan ketidaksamaan, tetapi sederajat, dan dapat diikat dengan "mutual respect" sehingga terbentuk satu kesatuan budaya. Perbedaan yang menonjol dan menjadi fokus perhatian adalah ras (etnik), agama dan jender.

Teori mulitukultural bukan hanya menghormati kemajemukan dari manusia itu sendiri tetapi dituntut adanya saling menghormati, dialog, kerjasama, menghargai keunikan budaya tujuannya untuk kehidupan masyarakat bersama dalam kemajemukan demi keutuhan dan kesatuan. ${ }^{9}$

Hardjosoemantri (2007) mengemukakan bahwa sikap kebersamaan didasarkan atas keyakinan bahwa pemecahan masalah secara bersama selalu baik daripada memecahkan sendiri, masalah yang bersifat kompleks yang tidak didasarkan atas mungkin dipecahkan oleh satu disiplin ilmu, lebih-lebih

\footnotetext{
${ }^{7}$ Ian Craib, Teori-Teori Sosial Modern Dari Parsons Sampai Habermas (Jakarta: Rajawali Press, 1994), 60.

${ }^{8}$ Paul B Harton, Sosiologi, 6th ed., 1 (Jakarta: Erlangga, 1984), 106.

${ }^{9}$ Sudardja Adiwikarta, "Handout Perkuliahan Mata Kuliah Sosiologi Pendidikan" (Bandung, 2010).
}

\section{PALITA: Journal of Social-Religion Research}


masalah pembangunan yang multi kompleks harus didekati dengan cara inter dan multidisipliner serta lintas sektoral. Sikap kebersamaan dalam konteks learning to live together, salah satu pilar pendidikan yang dicetuskan oleh UNESCO, adalah kebiasaan hidup bersama, saling menghargai, terbuka, member dan menerima pada masyarakat yang pluralis dengan keragaman ras, suku, agama/keyakinan dan budaya. Learning to live together mengemukakan beberapa aspek utamanya, yaitu: (1) respek (respect), (2) kebaikan hati (kindness), (3) keadilan (justice), dan bertanggung jawab (responsibility) ${ }^{10}$.

Dalam surat Al-Hujurat [49]: 13, yang bermakna bahwa manusia diciptakan dengan beragam dari suku-suku dan bangsa-bangsa yang berbeda agar saling mengenal. Dalam khazanah kita dikenal istilah Bhinneka Tunggal Ika yang berarti berbeda tapi tetap satu. Istilah ini untuk mendeskripsikan dan sebagai petunjuk bahwa 'bapak-ibu pendiri' bangsa ini sadar akan keragaman bangsa Indonesia ini. Dalam istilah modern Bhinneka (kemajemukan) sering diterjemahkan dengan pluralisme.

Pluralisme terdapat dalam berbagai hal: agama, kebenaran, kebudayaan, ilmu, ras dan lain sebagainya. Pluralisme juga dapat dijumpai di mana-mana. Dalam teks al-Qur'an, pluralisme bukan saja kehendak Tuhan, tapi juga kehendak sejarah (QS. Al-Ma'idah [5] : 48, Hud [11]:18 dan semuanya itu dimaksudkan agar manusia berlomba-lomba dalam mencari dan menempuh kebaikan (QS. Al-Baqarah [2]:147) dan saling mengenal potensi masing-masing sehingga tumbuh sikap bersama yang sehat seperti menggunakan segi-segi kelebihan masing-masing untuk mewujudkan kemaslahatan di masyarakat dan saling menutup kekurangan masingmasingnya. ${ }^{11}$ Yang perlu digarisbawahi adalah bahwa pluralisme bukan berarti relativisme absolut dan sinkretisme. Sebab, pluralisme bukan berarti menafikan adanya persamaan dan kebenaran yang relatif universal. Dalam setiap perbedaan, pasti ada persamaan dan kesatuan. Hal seperti ini ditegakkan sebelumnya, persamaan itu adalah pada kemanusiaannya.

\section{METODE}

Penelitian ini menggunakan pendekatan kualitatif dengan model Research and Development. Lokasi penelitian Forum Kerukunan Umat Beragama kota Palangka Raya yang berjumlahkan 17 orang. Teknik pengumpulan data dengan menggunakan dokumentasi, rekaman arsip,

${ }^{10}$ Clarry Sada, "Pengembangan Model Integrasi Nilai-Nilai Cinta Dalam Pembelajaran Bahasa Untuk Membentuk Sikap Kebersamaan (Studi Kasus Di SMA Negeri 2 Pontianak)" (Tidak DIterbitkan, Program Pascasarjana Universitas Pendidikan Indonesia, 2011).

${ }^{11}$ Ngainun Naim and Achmad Sauqi, Pendidikan Multikultural Konsep-Konsep Dan Aplikasi (Yogyakarta: Ar-Ruzz Media, 2010), 121-29. 


\section{6 | Desi Erawati}

wawancara, observasi langsung. Data yang terkumpul kemudian dianalisis secara kualitatif.

\section{KEADAAN SOSIAL PENDUDUK KOTA PALNGKA RAYA}

Provinsi Kalimantan Tengah yang beribu kota di Palangka Raya terletak diantara $0^{045}$ ' Lintang Utara, 3030' Lintang Selatan dan $111^{0}$ Bujur Timur. Terletak diantara 3 Provinsi tetangga yaitu disebelah Utara dengan sebagian wilayah Provinsi Kalimantan Barat dan Kalimantan Timur, disebalah Timur dengan sebagian Provinsi Kalimantan Timur dan Kalimantan Selatan diselat dengan laut Jawa dan disebelah Barat dengan Provinsi Kalimantan Barat.

Luas Kalimantan Tengah tercatat $153.564 \mathrm{~km}^{2}$. Dengan adanya pembentukan 8 Kabupaten baru yaitu sejak berlakunya UU No. 05 Tahun 2002, Provinsi Kalimantan Tengah meliputi 13 Kabupaten dan satu kota. Kabupaten Murung dan Kabupaten Katingan merupakan Kabupaten terluas, masing-masing $23.700 \mathrm{~km}^{2}$ dan $17.800 \mathrm{~km}^{2}$ atau luasnya keduanya Kabupaten tersebut menjapai 27\% dari seluruh Kalimantan Tengah. ${ }^{12}$

Menurut Tjilik Riwut sendiri kata Dayak itu pada kebanyakan orang berarti Orang Gunung, tetapi pengertian Dayak itu berarti orang gunung belum pernah ditemukan dalam kamus. Kemungkinan pengertian Dayak yang berarti orang gunung karena sebagian besar orang-orang Dayak tinggal di udik-udik sungai yang tanahnya berbukit-bukit. Tetapi bukannya kata Dayak berarti orang gunung. ${ }^{13}$

Dalam kehidupan sosial masyarakat dikenal dengan "Budaya Betang" hal mendasar dalam Budaya Betang ini, bahwa norma kehidupan masyarakat berdasarkan kekeluargaan, kebersamaan, kesetaraan dalam sistem masyarakat terbuka, sangat sesuai dengan ciri-ciri masyarakat Dayak Ngaju. Daerah Kalimantan Tengah didiami tidak hanya oleh suku Dayak tetapi juga Jawa, Banjar, Madura, maupun Tionghoa. Ada sekitar 10 suku Dayak dengan empat bahasa Dayak yang meliputi 250-an suku-suku kecil yang mendiami Kalimantan Tengah. Jika masyarakat Dayak Kalimantan Barat mengidentifikasikan diri mereka sebagai kelompok etnik pada satu agama Kristen, maka Dayak Kalimantan Tengah tidaklah demikian karena mereka tidak hanya mengarah pada satu kelompok atau sub-etnik tertentu tetapi kepada kelompok etnik Kalimantan Tengah secara keseluruhan. Hal inilah salah satu faktor pendorong bagi Kalimantan Tengah untuk lebih mudah mencari identifikasi etnik karena hampir semua etnik yang ada mampu

12 Badan Pusat Statistik Provinsi Kalimantan Tengah, Kalimantan Tengah Dalam Angka Kalimantan Tengah in Figures 2009 (Kalimantan Tengah: BPS Kalimantan Tengah, 2009).

${ }^{13}$ Tjilik Riwut, Kalimantan Membangun Alam Dan Kebudayaan (Yogyakarta: NR Publishing, 2007), 261-65.

\section{PALITA: Journal of Social-Religion Research}


'melebur' dengan menerima Banjar sebagai 'budaya bersama' dalam berinteraksi antar etnik yang ada. ${ }^{14}$

Keadaan penduduk Kota Palangka Raya sebanyak 182.264 jiwa. Dengan kepadatan penduduk rata-rata 71.61 tiap $\mathrm{km}^{2}$ penyebaran jumlah penduduk menurut wilayah kecamatan tidak merata. Sebagian besar terkonsentrasi di wilayah Jekan Raya, yaitu sebanyak 9.437 jiwa (49.49\%) dan Kecamatan Pahandut, yaitu sebanyak 7.142 jiwa (37.19\%). Kecamatan Sebangau 11.477 (5.98\%). Bukit Batu sebanyak 11.043 jiwa (5.76\%). Rakumpit sebanyak 3.033 jiwa (1.58\%). ${ }^{15}$ Selanjutnya dapat dilihat pada Tabel 1 berikut:

Tabel 1 Jumlah Penduduk Antar Umat Berbeda Agama di Kota Palangka Raya

\begin{tabular}{|c|l|l|l|l|l|l|}
\hline \multirow{2}{*}{ No } & \multirow{2}{*}{$\begin{array}{c}\text { KUA } \\
\text { Kecamatan }\end{array}$} & \multicolumn{5}{|c|}{ Jumlah Penduduk } \\
\cline { 3 - 7 } & Islam & Protestan & Katolik & Hindu & Buddha \\
\hline 1. & Pahandut & 43.215 & 16.779 & 4.394 & 1.362 & 396 \\
\hline 2. & Jekan Raya & 43.139 & 32.897 & 3.751 & 3.079 & 9 \\
\hline 3. & Sebangau & 10.202 & 700 & 600 & 400 & 300 \\
\hline 4. & Bukit Batu & 7.026 & 3.454 & - & 453 & 300 \\
\hline 5. & Rakumpit & 818 & 1.362 & 28 & 472 & - \\
\hline Jumlah & 104.400 & 55.192 & 8.773 & 5.766 & 1.005 \\
\hline
\end{tabular}

Sumber: Laporan Jumlah Penduduk dan Rumah Ibadah Palangka Raya Tahun $2008^{16}$

\section{MODEL AWAL SOSIALISASI NILAI KEBERSAMAAN}

Berdasarkan SKB 2 Menteri yaitu menteri dalam negeri dan menteri agama nomor: 9 tahun 2006/ nomor: 8 tahun 2006. Tentang pedoman pelaksanaan tugas kepala daerah/wakil kepala daerah dalam pemeliharaan kerukunan umat beragama, pemberdayaan forum kerukunan umat beragama dan pendirian rumah ibadah. Juga peraturan Gubernur Kalimantan Tengah, nomor 6 tahun 2007 tentang pembentukan forum kerukunan umat beragama (FKUB) dan dewan penasehat FKUB propinsi dan kabupaten/kota di Propinsi Kalimantan Tengah dan keputusan Walikota Palangka Raya nomor: 238 tahun 2007 tentang penetapan susunan kepengurusan FKUB dan dewan penasehat serta sekretariat FKUB kota Palangka Raya.

${ }^{14}$ Heru Cahyono, Konflik Kalbar Dan Kalteng Jalan Panjang Meretas Perdamaian (Yogyakarta: Pustaka Pelajar, 2008), 46-47.

${ }^{15}$ FKUB Kota Palangka Raya, Laporan Keberadaan Dan Aktivitas FKUB Kota Palangka Raya.

${ }^{16}$ Data Jumlah Penduduk, Rumah Ibadah Kecamatan Se Kota Palangka Raya, (2008). Laporan Jumlah Penduduk dan Rumah Ibadah Palangka Raya: DEPAG Kota Palangka Raya 


\section{8 | Desi Erawati}

Berdasarkan dari ketetapan ini, maka dibentuklah kepengurusan FKUB baik dari propinsi ataupun dari kota Palangka Raya. Dimana dalam pemilihan kepengurusan tersebut berdasarkan prosentase jumlah penduduk yang ada di kota Palangka Raya. Karena penduduk Islam sekitar 60, 27\% maka terpilih 9 orang pengurus, Kristen sekitar 31,72\% 3 orang, Katolik 3,37 \% 2 orang, kemudian Hindu sekitar 3,44\% 1 orang dan Buddha sekitar 1,17\% 1 orang. ${ }^{17}$

Kondisi model awal sosialisasi nilai kebersamaan terlihat pada Gambar 1 berikut ini:

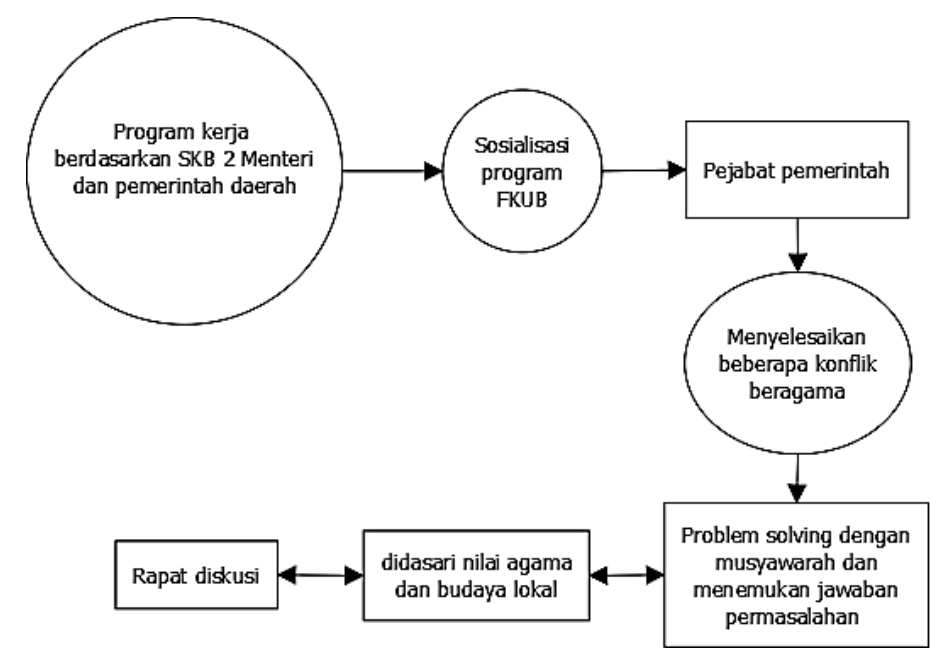

Gambar 1 Model Awal Sosialisasi Nilai Kebersamaan

\section{PENGEMBANGAN MODEL HIPOTETIK}

Mencermati langkah-langkah yang dilalui oleh pengurus FKUB dalam rangka sosialisasi nilai kebersamaan sebagai upaya menanggulangi konflik beragama dalam kehidupan masyarakat kota Palangka Raya, dapat dijabarkan langkah-langkahnya sebagai berikut :

1. Langkah pertama adalah mengadakan sosialisasi program kerja dan sasaran apa saja yang menjadi kajian FKUB.

2. Yang kedua sasaran daripada sosialisasi adalah masyarakat yang beraneka ragam dengan mensosialisasikan berbeda itu indah. Selain itu juga membahas tentan Peraturan Pendirian rumah ibadah dan ruang lingkupnya.

3. Dari potensi konflik tersebut kiranya menjadi pusat kajian bagi FKUB dengan cara meminimalisir potensi-potensi konflik antar umat berbeda agama di kota Palangka Raya.

4. Semua langkah tersebut tentunya sebagai pelaku utama adalah para pengurus FKUB yang sengaja terpilih dari perwakilan semua pemimpin Tahun 2009.

${ }^{17}$ Berdasarkan Kanwil Depag dan Biro Pusat Statistik Provinsi Kalimantan Tengah

PALITA: Journal of Social-Religion Research 
umat beragama yang ada di kota Palangka Raya, dimana penetapan jumlah maksimal diatur melalui prosentase penduduk kota Palangka Raya.

5. Para anggota FKUB sendiri dalam mengatasi permasalahan tentunya selalu berdasarkan dari beberapa nilai seperti nilai ideologi, nilai agama dan nilai budaya lokal setempat. Ketiga nilai tersebut termanifestasi dalam sikap pengendalian diri, penegakan moral, menumbuhkan rasa toleransi, menumbuhkan rasa tanggung jawab, tenggang rasa, berpikir positif dan berkomunikasi dengan baik (santun, bijaksana).

6. Itu semua terlaksana maka kerukunan hidup antar umat berbeda agama akan berjalan sesuai dengan apa yang diharapkan oleh pemerintah dan guna terciptanya pembangunan daerah yang aman, damai dan sejahtera.

7. Setelah semua berjalan secara sinergis maka perlu kiranya disosialisasikan kepada kalangan masyarakat bawah kiranya bersikap saling kerjasama antar umat berbeda agama, adanya kebebasan menjalankan syari'at agama masing-masing, saling percayamempercayai, saling menghormati dan saling menghargai satu dengan lainnya dan tak kalah penting guna terjalinnya komunikasi yang santun dengan beberapa kriteria yang ditawarkan seperti pola berbicara dengan jelas, baik, benar, mudah dicerna, lemah lembut, menghargai pendapat orang lain. ${ }^{18}$

Model hipotetik yang sudah dilakukan uji validasi lapangan dengan beberapa ahli dan teman sejawat, maka ditemukanlah revisi model hipotetik yang bisa dijadikan potakan khususnya yang berkenaan dengan kajian pengembangan model sosialisasi nilai kebersamaan sebagai salah satu upaya untuk mengatasi konflik beragama dalam kehidupan di masyarakat. Adapun langkah-langkah dalam uji coba pengembangan model sosialisasi nilai kebersamaan sebagai berikut:

1. Persiapan; pada tahap persiapan uji lapangan ini peneliti bersamasama dengan bahan-bahan contoh kasus yang berkaitan dengan rumah ibadah dan peserta FKUB melakukan kegiatan sebagai berikut:

a. Mengadakan identifikasi masalah

b. Merumuskan dan membaca contoh kasus yang sudah disiapkan

c. Membandingkan beberapa contoh kasus yang ditawarkan

2. Pelaksanaan; pelaksaan uji lapangan dilakukan dengan menggunakan keterlibatan peneliti, bahan-bahan contoh kasus baik itu berupa

${ }^{18}$ Sofyan Sauri, Pendidikan Berbasis Santun (Bandung: PT Granesindo, 2006), 79. 
artikel, fhoto ataupun gambar dan peserta FKUB dalam uji lapangan dapat dideskripsikan sebagai berikut:

a. Identifikasi masalah yang diberikan berupa fhoto/gambar dan artikel tentang kasus pendirian rumah ibadah dan ruang lingkupnya

b. Merumuskan dan mendiskusikan secara bersama-sama dari anggota FKUB

c. Mencari solusi yang baik dengan jalan musyawarah dan mengedepankan filosofi kearifan lokal.

3. Peneliti memonitor dan mengevaluasi pelaksanaan uji lapangan yang dilakukan oleh peserta FKUB.

4. Peneliti, dan peserta FKUB mendiskusikan hasil uji lapangan.

Dari revisi model hipotetik ini menggambarkan bahwa peran anggota FKUB kota Palangka Raya sangat penting guna terciptanya masyarakat beragama yang damai dengan mensosialisasikan semua program kerja yang ditargetkan yaitu tentang pendirian rumah ibadah dan pola hidup rukun antar umat berbeda agama guna mengatasi potensi konflik antar umat beragama. Nilai kebersamaan adalah sebagai kunci berhasilnya pola kerja FKUB karena dengan berdasarkan tiga nilai yaitu ideologi sebagai kebenaran yang universal Pancasila dan semboyan Bhinneka Tunggal Ika, juga agama menjadi dasar bahwa semua agama mengajarkan kedamaian, toleransi antar sesama. Yang terakhir adalah budaya kearifan lokal (Dayak) yaitu Huma Betang. Indikator nilai kebersamaan dapat dilihat sebagai berikut: Tenggang rasa, berkomunikasi dengan baik, menumbuhkan rasa toleransi, menumbuhkan rasa tanggung jawab, pengendalian diri dan penegakan moral. Maka akan terbentuk pola hidup rukun terlihat pada sikap adanya kerjasama antar umat beragama, kebebasan menjalan syari'at agama, saling menghormati dan menghargai ini akan tercipta kesejahteraan, keamanan, kedamaian yang itu semua diharapkan sebagai tujuan utama dari pola kerja FKUB kota Palangka Raya.

Uji efektivitas yang telah dilakukan terbukti pada indikator nilai kebersamaan seperti:

1. Tenggang rasa, dengan jumlah prosentase sangat tinggi $66,67 \%$, dan tinggi 33,33\%. Terbukti pada menyelesaikan beberapa masalah seperti kasus pembangunan mesjid yang alat kontraktornya adalah milik agama lain, kemudian penggunaan alat pengeras mesjid yang tidak sesuai dengan aturan. Hasil dari beberapa masalah tersebut FKUB bisa mengatasi dengan jalan kekeluargaan tanpa adanya prasangka yang kurang baik. Sikap demikian benar adanya karena menurut Hardjosoemantri (2007) bahwa setiap permasalahan itu akan lebih dipecahkan secara bersama-sama akan lebih baik daripada 
memecahkan sendiri, karena masalah keberagamaan itu adalah menyangkut dari semua kalangan agama dan tentunya hasilnyapun akan membawa kebaikan pula.

2. Berkomunikasi dengan baik ada beberapa orang yang bersikap sangat rendah 33,33\%. Dan yang bersikap sangat tinggi 33,33\% dan tinggi $33,33 \%$. Inilah terlihat adanya kekurangefektifan dari nilai kebersamaan tersebut, terlihat pada frekuensi pertemuan yang belum maksimal, dan tidak mengikuti kegiatan yang telah di programkan FKUB dengan maksimal.

3. Menumbuhkan rasa toleransi, untuk indikator ini terlihat sikap kebersamaannya sangat tinggi 100\%. Terbukti pada beberapa kegiatan seperti pada bulan Ramadhan diadakan program Safari Ramadhan yang diikuti oleh seluruh anggota FKUB kota Palangka Raya, kemudian mengadakan kunjungan ke rumah sesama anggota FKUB disaat pelaksanaan hari raya keagamaan, satgas pemuda FKUB ikut serta berpartisipasi dalam menjaga keamanan disaat perayaan hari raya keagamaan misalnya Idul Fitri, Idul Adha, Natal, Nyepi, Waisak dan lainnya. Kontribusi Islam terhadap toleransi juga dalam surat alHujurat [49]:13 mengindikasikan bahwa manusia diciptakan dengan beragam dari suku-suku dan bangsa-bangsa yang berbeda untuk saling kenal mengenal, sesuai dengan semboyan Bhinneka Tunggal Ika berbeda tapi tetap satu dan filosofi lokal Kalimantan Tengah "Huma Betang" (Penyang Hinje Simpei Paturung Humba Tamburak;bersatu/bersama dalam suatu ikatan yang kuat. Dan Hatangku Hakang Kalu; bersatu bersama/gotong royong) ${ }^{19}$.

4. Menumbuhkan rasa tanggung jawab berdasarkan prosentasenya sangat tinggi $66,67 \%$ dan tinggi $33,33 \%$. Terlihat pada berusaha melaksanakan seluruh program kerja yang telah ditetapkan bersama. Seperti mengadakan sosialisasi tentang peraturan SKB 2 Menteri no 9 dan 8 tentang FKUB dan pendirian rumah ibadah di lima kecamatan dan 30 desa yang ada dikota Palangka Raya. Melaksanakan kerjasama dengan instansi terkait seperti Polresta kota Palangka Raya dalam rangka menciptakan kerukunan dan menjaga stabilitas keberagamaan di kota Palangka Raya misalnya dalam pemberantasan penyakit masyarakat (pekat) seperti pelaksanaan judi "dadu gurak" yang biasa dilaksanakan oleh oknum masyarakat di saat hari kematian salah satu agama dan pelarangan penggunaan mercon/petasan di bulan Ramadhan.

${ }^{19}$ Lewis Parada, Tokoh Pemuda Dayak Provinsi Kalimantan Tengah, Tahun 2011. 


\section{2 | Desi Erawati}

5. Pengendalian diri berdasarkan prosentase yang didapatkan sangat tinggi 66,66\% dan ada yang bersikap sangat rendah 16,67\%. Terlihat pada khususnya dalam memutuskan atau mengatasi permasalahan yang berkaitan dengan keberagamaan terlihat memang sifat subyektivitas individu itu ada secara tidak langsung prasangka secara internal memang ada, hanya masing-masing anggota FKUB melihat kembali dengan dasar pembentukan FKUB sendiri untuk menciptakan kerukunan diantara sesama penganut beragama.

6. Penegakan moral, terlihat bahwa sikap sangat tinggi $83,33 \%$ dan tinggi 16,67\%. Dalam kinerjanya FKUB diantaranya bekerjasama dengan kepolisian polresta kota Palangka Raya dalam pemberantasan penyakit masyarakat. Setiap anggota FKUB yang merupakan tokoh di masingmasing agamanya menanamkan kepada umatnya masing-masing tentang pentingnya hidup rukun dan toleransi antar sesama umat beragama.

Sikap sosialisasi nilai kebersamaan yang dilakukan FKUB kota Palangka Raya terbukti pada skala sikap cukup baik terlihat pada Tabel 2 berikut ini :

Tabel 2 Kriteria Sikap Resonden Peritem Indikator

\begin{tabular}{|c|c|c|c|c|c|c|c|c|c|c|c|c|c|c|c|}
\hline \multirow{3}{*}{$\begin{array}{c}\begin{array}{c}\text { No } \\
\text { Rspdn }\end{array} \\
1\end{array}$} & \multicolumn{12}{|c|}{ ITEM INDIKATOR SIKAP } & \multirow{3}{*}{$\begin{array}{c}\text { Total } \\
471\end{array}$} & \multirow{3}{*}{$\begin{array}{c}\text { Rerata } \\
78,50 \\
\end{array}$} & \multirow{3}{*}{$\begin{array}{c}\text { Ket. Sikap } \\
\text { Tinggi }\end{array}$} \\
\hline & \multicolumn{2}{|c|}{1} & \multicolumn{2}{|c|}{2} & \multicolumn{2}{|c|}{3} & \multicolumn{2}{|c|}{4} & \multicolumn{2}{|c|}{5} & \multicolumn{2}{|c|}{6} & & & \\
\hline & 80 & $\mathrm{~T}$ & 47 & SR & 85 & ST & 84 & $\mathrm{~T}$ & 90 & SR & 85 & ST & & & \\
\hline 2 & 100 & ST & 73 & $\mathrm{~T}$ & 100 & ST & 100 & ST & 100 & ST & 100 & ST & 573 & 95,50 & Sangat Tinggi \\
\hline 3 & 100 & ST & 93 & ST & 100 & ST & 100 & ST & 95 & ST & 98 & ST & 589 & 98,17 & Sangat Tinggi \\
\hline 4 & 100 & ST & 47 & SR & 100 & ST & 100 & ST & 100 & ST & 100 & ST & 547 & 91,17 & Sangat Tinggi \\
\hline 5 & 100 & ST & 93 & ST & 100 & ST & 100 & ST & 95 & ST & 100 & ST & 588 & 98,00 & Sangat Tinggi \\
\hline 6 & 80 & $\mathrm{~T}$ & 80 & $\mathrm{~T}$ & 85 & ST & 80 & $\mathrm{~T}$ & 75 & $\mathrm{~T}$ & 78 & $\mathrm{~T}$ & 478 & 79,67 & Tinggi \\
\hline
\end{tabular}

Sumber: Data Olahan Hasil Penelitian

Keterangan:

ST (sangat Tinggi), T (Tinggi), C (Cukup), R (Rendah), SR (Sangat Rendah)

\section{PENUTUP}

Dari berbagai kajian yang telah dilakukan sampailah pada tahap kesimpulan dari analisa penelitian sebagai berikut:

Pertama, Berdasarkan SK Menteri Dalam Negeri dan Menteri Agama, Nomor: 9 dan 8 Tahun 2006, pembentukan kepengurusan FKUB kota Palangka didasarkan pada prosentase jumlah penduduk, dengan selalu mengedepankan keputusan musyawarah mencapai kesepakatan bersama, berfalsafahkan "Huma Betang". Kinerja sesuai program kerja yang sudah direncanakan, dengan mengadakan rapat rutin bulanan ataupun tahunan 
guna mengevaluasi kinerja FKUB dan menjadi masukan nantinya buat anggaran program kerja berikutnya. Bersama-sama untuk berdialog, berkomunikasi guna memecahkan masalah keberagamaan yang ada di masyarakat. Dengan begitu FKUB dapat mensosialisasikan bahwa dengan berbeda itu tidak menghalangi untuk membangun kota Palangka Raya yang cantik ini.

Kedua, Pengembangan model sosialisasi nilai kebersamaan yang ada di FKUB kota Palangka Raya menurut peneliti adalah atas dasar nilai ideologi, agama dan budaya. Karena semua ajaran agama itu selalu mengajarkan halhal positif (kebaikan) baik untuk intern umatnya dan agama yang lainnya tentunya. Sedangkan nilai ideologi adalah berdasarkan Pancasila sila Pertama dan Kedua juga UUD 1945 pasal 29 ayat dua dan semboyan Bhinneka Tunggal Ika. Sedangkan nilai budaya berfalsafahkan "Huma Betang (Penyang Hinje Simpei paturung Humba Tamburak; bersatu/bersama dalam suatu ikatan yang kuat), Hatangku Hakang Kalu; bersatu, bersama/gotong royong). Dari ketiga nilai tersebut maka dapat diindikasikan nilai kebersamaan itu: 1, Tenggang rasa, 2, berkomunikasi dengan baik, 3. Menumbuhkan rasa toleransi, 4. Menumbuhkan rasa tanggung jawab, 5. Pengendalian diri, 6. Penegakan moral.

Ketiga, Efektivitas nilai kebersamaan yang dilakukan oleh FKUB dengan indikasi (1) tenggang rasa bersikap sangat tinggi yaitu 66,67\%, (2) berkomunikasi dengan baik ada bersikap sangat tinggi yaitu 33,33\% dan ada juga sikap sangat rendah yaitu 33,33\%. (3) Menumbuhkan rasa toleransi $100 \%$ sangat tinggi, (4) menumbuhkan rasa tanggung jawab sangat tinggi $66,67 \%$, (5) pengendalian diri, beberapa orang bersikap $66,67 \%$ dan ada bersikap sangat rendah 16,67\%. (6) penegakan moral $100 \%$ sangat tinggi. Secara keseluruhan dapat disebutkan bahwa nilai kebersamaan yang dilakukan FKUB sangat tinggi berkisar dari rerata 78,50 - 98,17.

\section{DAFTAR PUSTAKA}

“-." Republika, September 15, 2010.

Adiwikarta, Sudardja. "Handout Perkuliahan Mata Kuliah Sosiologi Pendidikan." Bandung, 2010.

Badan Pusat Statistik Provinsi Kalimantan Tengah. Kalimantan Tengah Dalam Angka Kalimantan Tengah in Figures 2009. Kalimantan Tengah: BPS Kalimantan Tengah, 2009.

Cahyono, Heru. Konflik Kalbar Dan Kalteng Jalan Panjang Meretas Perdamaian. Yogyakarta: Pustaka Pelajar, 2008.

Craib, Ian. Teori-Teori Sosial Modern Dari Parsons Sampai Habermas. Jakarta: Rajawali Press, 1994.

FKUB Kota Palangka Raya. Laporan Keberadaan Dan Aktivitas FKUB Kota Palangka Raya. Kalimantan Tengah Palngka Raya: FKUB, 2009. 


\section{4 | Desi Erawati}

Harton, Paul B. Sosiologi. 6th ed. 1. Jakarta: Erlangga, 1984.

Henslin, James M. Sosiologi Dengan Pendekatan Membumi. 6th ed. 1. Jakarta: Erlangga, 2006.

Johson, Doyle Paul. Teori Sosiologi Klasik Dan Modern. II. Jakarta: PT. Gramedia Pustaka Utama, 1986.

Naim, Ngainun, and Achmad Sauqi. Pendidikan Multikultural Konsep-Konsep Dan Aplikasi. Yogyakarta: Ar-Ruzz Media, 2010.

Narwoko, J.D., and Suyanto B. Sosiologi, Teks Pengantar Dan Terapan. 2nd ed. Jakarta: Prenada Media Group, 2006.

Sada, Clarry. "Pengembangan Model Integrasi Nilai-Nilai Cinta Dalam Pembelajaran Bahasa Untuk Membentuk Sikap Kebersamaan (Studi Kasus Di SMA Negeri 2 Pontianak)." Tidak DIterbitkan, Program Pascasarjana Universitas Pendidikan Indonesia, 2011.

Sauri, Sofyan. Pendidikan Berbasis Santun. Bandung: PT Granesindo, 2006. Sunarto, Kamanto. Pengantar Sosiologi. Edisi Revisi. Jakarta: UI Press, 2004. Tjilik Riwut. Kalimantan Membangun Alam Dan Kebudayaan. Yogyakarta: NR Publishing, 2007. 